\title{
Government Collaboration Model for Disaster Management Policy in West Bandung Regency
}

\author{
Deddy Mulyadi*, Riky Rinaldy Maulana \\ Polytechnic of STIA LAN \\ Bandung, Indonesia \\ *deddymulyadi@poltek.stialanbandung.ac.id, riky.rinaldy@ poltek.stialanbandung.ac.id
}

\begin{abstract}
West Bandung Regency is one of the districts in West Java Province with a very large potential for disaster, where of the 11 types of disasters, West Bandung Regency has 9 potential disasters, besides that the West Bandung area is overworked by two faults, namely the Lembang fault and the Cimandiri fault. Disaster management in West Bandung Regency will be a major thing that must be done by the West Bandung Regency government because this potential disaster will be a big problem if the government is unable to mitigate and socialize to the community to tie the potential of the disaster caused. Because of this shifting of faults, the government must be able to collaborate with all elements in carrying out disaster management, so that it can unravel the impact of disasters. In this study using descriptive qualitative research methods, with data collection techniques through direct observation, in-depth interviews with local government and review of written documentation. The government od West Bandung Regency realizes that the involvement of multi-stakeholders is needed in the implementation of disaster management because in West Bandung Regency the involvement of stakeholders and the disaster management model is not conducting well because the institutional factors of the regional Disaster management agency are less strong than the bureaucratic structure that is weak in function and lack of human resources. Therefore, to solve this problem, there must be a strengthening of the institution and forming a forum as a forum for the gathering of stakeholders from various elements, namely the Disaster Risk Reduction Forum. With this forum, the actors perform their respective functions by coordinating and cooperating with each other. In Collaborative Governance theory, we can see how local governments can optimize the role of each stakeholder in disaster management, this will become a good model when it could be applied.
\end{abstract}

Keywords-disaster, collaborative government, disaster management

\section{INTRODUCTION}

Disaster management becomes a comprehensive and proactive effort starting from disaster risk reduction, emergency response, and rehabilitation and reconstruction. It is an effort made jointly by stakeholders with complementary roles and functions. Basically, disaster management is part of the development process to create resilience to disasters.
Disaster management is currently regulated in Law Number 24 of 2007 which has brought a new dimension in disaster management in Indonesia. The law requires disaster management to be carried out in a decentralized manner by involving the widest possible participation of the community, starting from the early stages of the program (identification, analysis, implementation of work plans, monitoring and evaluation) to the final stage where the program will be fully handed over to local communities. Article 57 of Law Number 24 of 2007 states that disaster management at the pre-disaster stage includes prevention and preparedness.

West Bandung Regency is one of the areas that has the potential for major disasters in West Java because in the West Bandung Regency area there are 9 out of 11 disasters, namely: Earthquakes, volcanic eruptions, landslides, floods, flash floods, drought, forest fires, wind tornadoes, and hurricanes, only Tsunamis and abrasions have no potential. West Bandung also has 2 slabs or faults, namely the Lembang plate and the Cimandiri plate. Referring to research (McCalpin, 1996b; Wallace, 1986; Yeats et al., 1997a in Daryono [1]), the Lembang fault is an active fault that will produce disasters in the future and endanger the community. Such a disaster can disrupt the economic and social stability of the community, so the resilience and strength of the community must be prepared mentally to be resilient and resilient (resilience). Furthermore, Waluyo Handoko's [2] research explains the importance of expanding space for a bottom-up style in community development programs.

The area that is on the Lembang Fault route includes five sub-districts in West Bandung Regency. In these five subdistricts, there are 21 villages with many houses and densely populated areas right above the Lembang Fault, a dangerous location because current technology cannot predict the time of occurrence and the magnitude of the earthquake that will occur. Therefore, to reduce its impact, it is necessary to increase awareness and preparedness in dealing with disasters through the process of disaster management.

Regional disaster management is the main thing in reducing disaster risk. Seeing this phenomenon, according to Pramono [3], if a disaster management strategy becomes a reference in the response to human behavior or social groups in facing a 
disaster threat to become more effective, then this strategy needs to be developed and implemented as part of human life, or groups that experience a threat of disaster in their daily life. Pramono is inclined to make disaster management a preventive measure in aspects of everyday life.

Preventive action is a referral action from experts for something that is considered to cause chaos or chaos. Disaster mitigation is one of them. Regardless, taking preventive action requires conformity from various aspects. Readiness, acceptance and adjustment. To achieve the expected goals, is the fulfillment of functions from various intersecting sides. So it can be said that to achieve a goal there are systems that meet each other. This is to avoid failure of preventive procedures so that every element of society can complement each other to achieve common goals.

\section{LITERATUR REVIEW}

\section{A. Disaster Management}

Pujiono [4], which defines disaster management as a collection of activities covering all aspects of planning, prevention, risk management, and response to disaster events both before and after a disaster occurs.

From this opinion, in general, disaster management activities can be divided into three main activities, namely:

- Pre-disaster activities; includes prevention, mitigation, preparedness, and early warning activities.

- Activities when a disaster occurs; includes emergency response activities to alleviate temporary suffering, such as search and rescue (SAR), aid and evacuation activities.

- Post-disaster activities; includes recovery, rehabilitation, and reconstruction activities.

See figure 1 below.

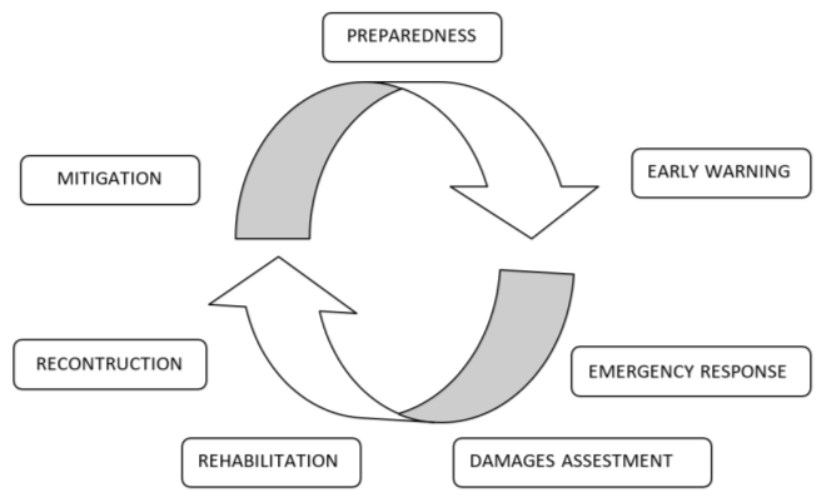

Fig. 1. Disaster management stages circle.

\section{B. Collaborative Government}

The main elements or principles of Collaborative Governance used in realizing sustainable regional disaster mitigation consist of 6 factors adopted from research [5] that is:

- Inclusive stakeholder involvement

- Promotion of institutional capacity

- Stakeholder collaborative leadership

- The role of a facilitator

- The Role of Education and Training and

- Institutional design.

The Collaborative Governance model according to Ansell and Gash [6] consists of several stages, namely:

- Starting Condition: In the initial condition stage in the relationship between stakeholders, each actor has a different background which can produce an asymmetrical relationship in the relationship that is carried out.

- Leadership in Ansell and Gash identifies three components of effective collaborative leadership, namely:

- Sufficient management of the collaborative process.

- Management of the ability to carry out technical credibility.

- Ensure that the collaboration is empowered to make credible and convincing decisions for all actors.

- Ansell and Gash's institutional design describes that Institutional Design refers to the basic protocol and the basic rules for collaboration which most critically emphasize is procedural legitimacy in the collaboration process. In the collaborative process, it must be emphasized that the government must be open and inclusive.

- The Collaborative Process The collaborative process model develops collaboration as a developmental stage. Gray in Ansell and Gash defines three stages of the collaboration process, namely: problem setting, direction setting, and implementation. The stages of forming a collaborative are as follows:

- Face to face

- $\quad$ Trust Building

- Commitment to process

- Share Understanding

- Outcomes 


\section{Methodology}

The method used in this research is descriptive qualitative. The data collection technique used in this study was to observe in the West Bandung Regency government environment, especially in the Bappeda and BPBD environment, in-depth interviews with several resource persons who understand this research, and literature study by collecting documents that support this research. From the data collection method, data analysis techniques are used in the form of a combination of all the data used. Data collection in this activity consists of secondary data and primary data. Secondary data is directed to documents related to local organizations. Meanwhile, primary data is directed to gather information directly in the field.

\section{RESULTS AND DISCUSSION}

Natural disasters are unavoidable and life-threatening events. The most appropriate action is to minimize losses before a disaster occurs with mitigation procedures. In all disaster events, it is important to understand what patterns of knowledge of individuals or communities about a disaster threat are and how their patterns can deal with these threats [7] Managing emergency response to disasters requires the implementation of a theoretical model that is based on local resources rather than on the basis of decisions by local authorities [8]. Thus, increasing public knowledge of disaster response management is the most important element. In line with this, the will and capacity of the community must also be supported by an appropriate adaptation pattern.

West Bandung Regency is one of the areas that has a fairly large potential for disaster where in addition to 9 potential disasters it also has 2 plates or faults that stretch and one of the faults is the Lembang Fault covering five districts in West Bandung Regency In these five sub-districts, there are 21 villages with many houses and densely populated areas right above the Lembang Fault, a dangerous location because current technology cannot predict the time of occurrence and the magnitude of the earthquake that will occur. Therefore, to reduce its impact, it is necessary to increase awareness and preparedness in facing disasters through the process of disaster management.

Disaster management is currently regulated in Law Number 24 of 2007 which has brought a new dimension in disaster management in Indonesia. The law requires disaster management to be carried out in a decentralized manner by involving the widest possible participation of the community, starting from the early stages of the program (identification, analysis, implementation of work plans, monitoring and evaluation) to the final stage where the program will be fully handed over to local communities. In other words, the community is the main actor in disaster management activities in their respective regions. The involvement of local communities as the main actors in disaster management is also supported by the international strategy for disaster risk reduction [9], one of its strategies is to involve community participation in the implementation of disaster risk reduction.
This community participation will not happen if the government does not have a collaboration model that can accommodate all the elements involved, so in this study the concept of the Collaborative Governance Model according to Ansell and Gash [6] which will see how the government collaborates in implementing disaster management in West Bandung Regency.

\section{A. Starting Condition}

In disaster management in West Bandung Regency, currently it has not become the main priority of the West Bandung Regency government, it can be seen from the budget and facilities that BPBD has are still far from sufficient so this is one of the problems that must be addressed immediately in order to optimize existing resources. In addition, the actors involved in the implementation of this countermeasures are still not involved as a whole, where at the village base level alone in determining DESTANA (Desa Tangguh Bencana / Disaster Resilient Village) in West Bandung Regency there are only 2 existing villages so that local institutions are still not well formed.

Therefore, the development of this local organization is one of the important points in disaster management because it can increase community participation and also raise awareness from the community.

\section{B. Leadership}

BPBD West Bandung Regency is led by the Regional Secretary of KBB and for daily tasks led by the Chief Executive. This becomes one of the obstacles in making decisions that require speed of handling. In this BPBD structure, if seen with the current conditions, it is better to carry out organizational restructuring where the head of the BPBD is directly held by the head of the agency directly so that when making decisions and when carrying out activities it will make coordination easier, because the two leaders can be one of the barrier factors to the progress of collaboration.

\section{Institutional Design}

Collaboration in disaster management in $\mathrm{KBB}$ is still being carried out by the local government. Even now, the DESTANA group that should be owned by each village, there are only 2 villages and the other villages are still in the formation process, especially in West Bandung. Apart from that, there is a lack of community organizations engaged in disaster management in West Bandung Regency.

This should be the concern of the Bandung Regency Government where when the West Bandung Regency government wants to apply the Pentahelix concept in terms of government collaboration, Institutional Strengthening is the main thing to make before collaborating so that in implementing collaboration all the elements involved have an appropriate role and can carry out a job well that involves various elements of the institution, but it is still not well realized. 


\section{Collaboration Process}

The current collaboration is only between institutions in the West Bandung Regency government when a disaster occurs, but for this disaster prevention program there is still no collaboration that is going well.

\section{E. Model}

In implementing disaster management, the main thing to do is that we can map the existing potential disasters (Disaster Management problems) which we will compile so that we can make a policy or the main basis for implementing disaster management activities, after the policy is compiled it will then be implemented by the implementers. and When the results are not in accordance with the results, then it is re-optimized by using the concept of the Collaborative Governance principle and the Collaborative Governance model so that it will produce a governance model between institutions in Regional Disaster Management. After this model comes out, the expected output is disaster management. See figure 2 below.

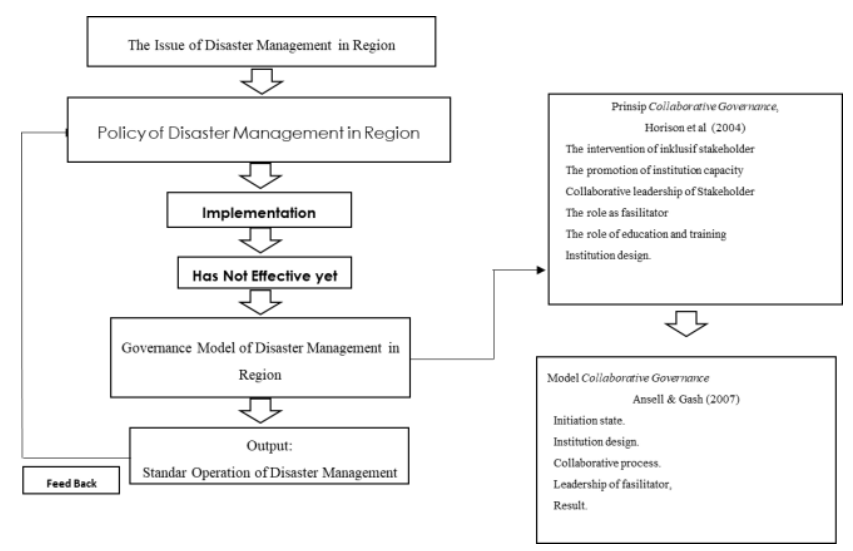

Fig. 2. Disaster management model.

\section{CONCLUSION}

The implementation of disaster management in West Bandung Regency is still not optimal where in the formation of only local elements, in this case DESTANA has only been formed in 2 villages, which should have all been formed in the district of West Bandung, besides that the collaboration currently taking place is still only between organizations Regional apparatus still does not involve other organizations such as universities, the private sector, community organizations and others, this must be optimized in order to build a collaborative model that involves all elements of society.

\section{ACKNOWLEDGMENT}

Thank you to the STIA LAN Bandung Polytechnic, which has given us the opportunity to conduct this research and support all the activities that we have compiled and also thank you for the West Bandung regency government for accepting us to conduct research in the West Bandung area.

\section{REFERENCES}

[1] M.R. Daryono, "Paleoseismologi Tropis Indonesia (Dengan Studi Kasus Di Sesar Sumatra, Sesar Palukoro-Matano, Dan Sesar Lembang), 2016.

[2] W. Handoko, "Menjaga Sustainabilitas Pengembangan Masyarakat Pesisir Kebumen: Antara Corak Top-Down, Partisipatif Dan Inisiasi Kelembagaan Lokal," Sosiohumaniora, vol. 19, no. 3, pp. 244-252, 2017.

[3] R. Pramono, "Perspektif Sosiologis Dalam Penanggulangan Bencana," Jurnal Masyarakat \& Budaya, vol. 18, no. 1, 2016.

[4] P. Pujiono, Kerangka Kerja Penanggulangan Bencana Berbasis Komunitas, 2008.

[5] P. Healey, Collaborative Planning : Shaping Places in Fragmented Societies. UBC Press, 2006.

[6] C. Ansell and A. Gash, "Collaborative governance in theory and practice," Journal of public administration research and theory, vol. 18, no. 4 , pp. $543-571,2008$.

[7] T.E. Drabek, Disaster Evacuation in the Tourist Industri. Boulder, Colorado: Institute of Behavioral Science, University of Colorado, 1991.

[8] R.R. Dynes and T.E. Drabek, "The Structure f Disaster Research: Its Policy and Disciplinary Implications," International Journal Of Mass Emergencies and Disaster, 1994.

[9] A.W. Coburn, Modul Mitigasi Bencana. UNDP, United Kingdom, 1994. 